\title{
PENINGKATAN AKTIVITAS DAN HASIL BELAJAR BIOLOGI DENGAN MODEL PEMBELAJARAN EXAMPLE NON EXAMPLE
}

\author{
Maryono \\ SMA NEGERI 1 SITIUNG \\ Email: maryonositiung@gmail.com
}

\begin{abstract}
This classroom action research examines how to improve learning activities and students' ability to master the concept of genetic substances and cell division through the application of the Example non example learning model in achieving competency in learning biology. The subjects of this study were students of class XII IPA-3 SMA Negeri 1 Sitiung. The method used by CAR and processed descriptively qualitatively. The technique used to collect data uses an observation sheet as a data collection tool that is filled out by the observer during the learning process. From the results of the study it can be concluded that the application of the Example non example learning model can increase student activity and learning outcomes in solving biological problems, especially genetics and cell division. On. In the first cycle the classical completeness of the first meeting $=16 \%$ and the second meeting $=45 \%$, while in the second cycle it increased at the first meeting $=77 \%$ and the second meeting increased to $97 \%$.

Keywords: increased activity, learning outcomes, model example non example
\end{abstract}

\begin{abstract}
Abstrak
Penelitian tindakan kelas ini meneliti bagaimana meningkatkan aktivitas belajar dan kemampuan siswa dalam penguasaan konsep substansi genetika dan pembelahan sel melalui penerapan model pembelajaran Example non example dalam mencapai kompetensi belajar biologi. Subjek penelitian ini adalah siswa kelas XII IPA-3 SMA Negeri 1 Sitiung. Adapun metode yang digunakan PTK dan diolah secara deskriptif kualitatif. Teknik yang digunakan untuk mengumpulkan data menggunakan lembar observasi sebagai alat pengumpul data yang diisi oleh observer selama pembelajaran berlangsung. Dari hasil penelitian dapat disimpulkan bahwa penerapan model pembelajaran Example non example dapat meningkatkan aktivitas dan hasil belajar siswa dalam memecahkan masalah biologi khususnya materi substansi genetika dan pembelahan sel. Pada. Pada siklus I ketuntasan klasikal pertemuan $\mathrm{I}=16 \%$ dan pertemuan II $=45 \%$, sedangkan pada siklus II meningkat pada pertemuan I $=77 \%$ dan pertemuan II meningkat menjadi $97 \%$.

Kata kunci: peningkatan aktivitas, hasil belajar, model example non example
\end{abstract}

\section{PENDAHULUAN}

\section{Latar belakang masalah}

Berdasarkan hasil observasi awal terhadap keberhasilan proses pembelajaran di kelas XII MIA 3 SMA Negeri 1 Sitiung. Hasil UH yang telah dilaksanakan dari 28 orang siswa hanya 11 orang tuntas dengan nilai rata-rata 7,0 yang sebagiannya berada di bawah KKM (Kriteria Ketuntasan Minimal) yang ditetapkan yaitu 73. Rendahnya hasil belajar siswa,berhubungan dengan perilaku 
siswa dalam proses belajar mengajar, siswa cenderung pasif, tidak merespon pelajaran yang diberikan dan kurang antusias dalam menerima pelajaran. Siswa tidak mau bertanya dan tidak pula bisa menjawab kalau diberi pertanyaan. Oleh karena itu menerapkan model pembelajaran Example Non Example dapat meningkatkan aktivitas dan hasil belajar siswa dalam memecahkan masalah biologi khususnya materi substansi genetika dan pembelahan sel.

Proses pembelajaran biologi merupakan implementasi dari konsep pendidikan biologi. Menurut Wuryadi (1999), obyek pendidikan biologi tersebut merupakan satu kesatuan interaktif yang terbentuk dari tiga komponen, yaitu biologi sebagai ilmu, karakteristik-karakteristik subyek didik dan teknologi pendidikan. Sedangkan biologi sebagai ilmu memiliki karakteristik sendiri, yaitu mempunyai obyek, gejala dan persoalannya; menggunakan metodologi ilmiah; memiliki kecenderungan untuk berkembang; dan bermanfaat bagi masyarakat .

\section{Aktivitas Belajar}

Aktivitas dapat dipahami sebagai serangkaian kegiatan jiwa raga psikofisik, menuju ke perkembangan individu seutuhnya yang menyangkut unsur cipta (kognitif), rasa (afektif) dan karsa (psikomotor). Aktivitas belajar adalah aktivitas yang bersifat fisik maupun mental dan dalam kegiatan belajar kedua aktivitas ini harus selalu berkait". Selama proses aktivitas belajar, diharapkan terjadi aktivitasaktivitas positif yang dilakukan oleh siswa. Ada delapan aktivitas pembelajaran yang meliputi "visual activities, oral activities, listening activities, writing activites, drawing activities, motor activites, mental activities, dan emosional activites".

1) Visual activities, yaitu termasuk didalamnya misalnya membaca, memperhatikan gambar, demonstrasi, percobaan, pekerjaan orang lain.

2) Oral activities, seperti menyatakan, merumuskan, bertanya, memberikan saran, mengeluarkan pendapat, mengadakan wawancara, diskusi, interupsi.

3) Listening activities, seperti mendengarkan uraian, percakapan, diskusi, mimik, pidato.

4) Writing activites, seperti menulis cerita, karangan, laporan, angket, menyalin.

5) Drawing activities, seperti menggambar, membuat grafik, peta dan diagram.

6) Motor activites yang termasuk didalamya antara lain : melakukan percobaan, membuat konstruksi, model mereparasi, bermain, berkebun, berternak.

7) Mental activities, sebagai contoh menganggap, mengingat, mencocokkan soal, menganalisis, melihat hubungan, mengambil keputusan.

8) Emosional activites, seperti menaruh minat, merasa bosan, gembira, bersemangat, bergairah, berani, tenang, gugup (Sardiman : 2006).

\section{Model pembelajaran Example Non Example}

Menurut Rochyandi, Yadi (2004:11) model pembelajaran kooperatif tipe example non example adalah:

"Tipe pembelajaran yang mengaktifkan siswa dengan cara guru menempelkan contoh gambar-gambar yang sesuai dengan tujuan pembelajaran dan gambar lain yang relevan dengan tujuan pembelajaran, kemudian siswa disuruh untuk menganalisisnya dan mendiskusikan hasil analisisnya sehingga siswa dapat membuat konsep yang esensial." 
Model Pembelajaran Example Non Example atau juga biasa di sebut example and non-example merupakan model pembelajaran yang menggunakan gambar sebagai media pembelajaran. Penggunaan media gambar ini disusun dan dirancang agar anak dapat menganalisis gambar tersebut menjadi sebuah bentuk diskripsi singkat mengenai apa yang ada didalam gambar. Konsep pada umumnya dipelajari melalui dua cara, paling banyak konsep yang kita pelajari di luar sekolah melalui pengamatan dan juga dipelajari melalui definisi konsep itu sendiri. Example and Nonexample adalah taktik yang dapat digunakan untuk mengajarkan definisi konsep.

\section{METODOLOGI}

\section{Lokasi dan Waktu Penelitian}

Penelitian tindakan kelas ini dilakukan pada semester satu tahun pelajaran 2019/2020 untuk mata pelajaran biologi di SMA Negeri 1 Sitiung Kabupaten Dharmasraya. Siswa yang menjadi subjek penelitian kelas XII MIA-3 berjumlah 28 orang terdiri dari 12 orang laki-laki dan 16 orang perempuan. Dalam melaksanakan penelitian peneliti dibantu oleh observer. Penelitian ini dilaksanakan dari tanggal 10 September sampai 30 November 2019. Pelaksanaan penelitian dilakukan dalam dua siklus masing-masing siklus 2 kali pertemuan, dengan jadwal penelitiannya sebagai berikut: Pra Siklus dilaksanakan pada Tanggal 15 Oktober 2019 dengan materi Metabolisme Sel Siklus I dilaksanakan pada tanggal 22 dan 29 Oktober 2019 dengan materi Substansi Genetika waktu selama 4 (empat) jam pelajaran. Siklus II dilaksanakan pada tanggal 1 dan 5 November 2019 dengan materi Pembelahan Sel, waktu selama 4 (empat) jam pelajaran.

\section{Prosedur Penelitian}

Penelitian tindakan kelas menggunakan model pembelajaran Example Non Example. Setiap siklus secara garis besar dengan langkah-langkah sebagai berikut:

\section{1) Tahap Perencanaan}

Sebelum melaksanakan penelitian, peneliti melakukan berbagai persiapan awal, yaitu : Merancang kegiatan pembelajaran dengan menerapkan model pembelajaran Example Non Example. Membagi siswa dalam kelompokkelompok kecil yang masing-masing kelompok terdiri dari 2-3 orang dengan latar belakang yang bervariasi, baik jenis kelamin, tingkat kecerdasan, suku, agama dan tingkat kecerdasan biologinya. Masing-masing kelompok berdiskusi untuk menentukan siapa yang menjadi ketua kelompok.

2) Tahap Pelaksanaan Tindakan

Guru menyampaikan tujuan dan mempersiapkan siswa dalam kelompoknya masing-masing. Guru menyampaikan pengetahuan awal dan keterampilan dalam menganalisa materi, bisa juga ditayangkan melalui Power Point. Guru memberikan contoh pelatihan soal dan memberi kesempatan siswa untuk memahami konsep materi yang disampaikan. Guru mengecek pemahaman dengan cara memberi umpan balik. Masing-masing kelompok menyampaikan hasil latihannya. Dan guru memberikan penjelasan / penegasan materi sesuai dengan tujuan pembelajaran yang ingin dicapai.. Guru memberi kesempatan untuk latihan lanjutan.

3) Tahap Pengamatan

Tahap pengamatan dilakukan pada saat kegiatan sedang berlangsung. Pada penelitian ini peneliti menggunakan lembar observasi mengenai motivasi 
siswa dalam belajar Biologi dan lembar observasi kegiatan guru dengan masing-masing menerapkan model pembelajaran Example Non Example.

4) Tahap Refleksi

Guru dan observer menganalisis dan merefleksi pelaksanaan hasil tindakan I. Untuk keperluan analisis ini dilakukan kegiatan antara lain memeriksa lembar observasi. Hasil analisis dan refleksi terhadap tindakan I ini menjadi bahan pelaksanaan tindakan berikutnya. Berikutnya dilanjutkan dengan pelaksanaan pembelajaran siklus II dengan bertitik tolak pada hasil refleksi pada siklus I. Kemudian menganalisis dan melakukan refleksi keseluruhan tindakan pembelajaran dengan menerapkan model pembelajaran Example Non Example). Kegiatan ini merupakan akhir dari tindakan I sampai tindakan II.

\section{HASIL PENELITIAN DAN PEMBAHASAN \\ Deskripsi Hasil Penelitian Terhadap Aktivitas Belajar Siswa \\ Deskripsi Kondisi Awal}

Kondisi awal di kelas XII MIA 3 SMAN Negeri 1 Sitiung terkait dengan model pembelajaran yang digunakan oleh guru dalam mata pelajaran biologi antara lain pertama, kebanyakan siswa kurang bisa mengerjakan soal-soal yang berhubungan dengan perhitungan matematika. Kedua, metode pembelajaran monoton dan teacher centered atau lebih berpusat pada guru menimbulkan siswa bosan. Ketiga, rendahnya kemampuan siswa dalam memecahkan soal-soal yang berhubungan dengan materi polapola hereditas, sehingga siswa cenderung pasif. Dari 28 siswa terdapat 20 siswa diam saja dalam belajar serta 23 siswa yang perlu mendapat bimbingan/bantuan secara individual dalam penyelesaian soal.

\section{Siklus Pertama}

Tabel: 1. Hasil observasi Aktivitas Belajar Siswa Dalam Pembelajaran Substansi Genetika Pada Siklus Pertama

\begin{tabular}{|c|c|c|c|c|c|}
\hline \multirow{2}{*}{ No } & \multirow{2}{*}{ Aktivitas siswa } & \multicolumn{2}{|c|}{ Pertemuan } & \multirow{2}{*}{ Rata-rata } & \multirow{2}{*}{$\%$} \\
\hline & & 1 & 2 & & \\
\hline 1 & Siswa bertanya & 15 & 20 & 17.5 & 67 \\
\hline 2 & $\begin{array}{l}\text { Siswa menjawab pertanyaan saat diskusi antar } \\
\text { kelompok }\end{array}$ & 15 & 18 & 16.5 & 63 \\
\hline 3 & $\begin{array}{l}\text { Siswa mengerjakan latihan soal yang diberikan } \\
\text { guru }\end{array}$ & 18 & 22 & 20.0 & 77 \\
\hline 4 & $\begin{array}{l}\text { Siswa berbicara tentang masalah lain saat } \\
\text { pembelajaran berlangsung }\end{array}$ & 3 & 2 & 2.5 & 10 \\
\hline 5 & $\begin{array}{l}\text { Siswa diam saja saat proses pembelajaran } \\
\text { berlangsung }\end{array}$ & 10 & 8 & 9.0 & 35 \\
\hline 6 & Siswa tidak konsentrasi saat belajar & 8 & 5 & 6.5 & 25 \\
\hline 7 & $\begin{array}{l}\text { Siswa diberi pujian atau penguatan oleh guru saat } \\
\text { belajar }\end{array}$ & 7 & 10 & 8.5 & 33 \\
\hline \multirow[t]{2}{*}{8} & $\begin{array}{l}\text { Siswa dibantu secara individual dalam } \\
\text { menyelesaikan soal-soal dalam kelompok kecil }\end{array}$ & 20 & 18 & 19.0 & 73 \\
\hline & Rata-rata & & & 12.4 & \\
\hline
\end{tabular}

Pada Tabel 1 terlihat bahwa aktivitas belajar siswa dalam pembelajaran biologi pada siklus I mengalami peningkatan dan aktivitas buruk yang biasa dilakukan peserta didik saat belajar mengalami penurunan untuk pengamatan pada indikator siswa yang bertanya hanya $67 \%$, siswa menjawab pertanyaan saat 
diskusi antar kelompok adalah 63\%, Siswa mengerjakan latihan soal yang diberikan guru adalah $77 \%$, siswa berbicara tentang masalah lain saat kerja kelompok atau saat pembelajaran berlangsung adalah $10 \%$, siswa diam saja saat proses belajar sedang berlangsung(karena tidak mengerti) adalah 35\%, siswa tidak konsentrasi saat proses belajar berlangsung adalah $25 \%$, siswa diberi pujian atau penguatan oleh guru adalah $33 \%$, siswa dibantu oleh guru secara individual dalam menyelesaikan soal-soal dalam kelompok kecil adalah $73 \%$.

\section{Hasil Belajar Siklus I}

Data kalkulasi nilai harian sebagai hasil belajar siswa pada siklus I adalah sebagai berikut:

Tabel 2. Nilai rata-rata hasil belajar siswa dalam menyelesaikan soal-soal substansi Genetika pada akhir siklus I $(\mathrm{KKM}=73)$

\begin{tabular}{|c|c|c|c|c|}
\hline No & Nilai & Jumlah Siswa & Tuntas & Tidak Tuntas \\
\hline 1 & $<49$ & 0 & 0 & 0 \\
\hline 2 & $50-59$ & 7 & 0 & 7 \\
\hline 3 & $60-69$ & 9 & 0 & 9 \\
\hline 4 & $70-79$ & 6 & 2 & 4 \\
\hline 5 & $80-89$ & 3 & 3 & 0 \\
\hline 6 & $90-100$ & 3 & 3 & 0 \\
\hline & Jumlah & 28 & 8 & 20 \\
\hline & Persentase & & 25.81 & 74.19 \\
\hline
\end{tabular}

Sumber: Tabulasi data, 2019

Dari total rata-rata perolehan nilai siswa walau sudah mengalami peningkatan tiap pertemuan, tapi rataan totalnya masih belum mencapai nilai KKM yaitu 73, dan persentase yang tuntas baru mencapai $26 \%$. Hal ini membuat harus ada perbaikan pada siklus berikutnya baik pelatihan kembali cara memecahkan soal-soal pola-pola hereditas di awal belajar siswa maupun penguatan di akhir tiap pertemuan.

\section{Refleksi}

Hasil analisis siklus pertama ini dijadikan bahan untuk memperbaiki tindakan yang akan diberikan berikutnya. Beberapa hal positif yang dapat dikemukakan dari siklus pertama adalah adanya siswa yang bertanya dan menjawab saat pembelajaran berlangsung yaitu siswa yang bertanya saat proses pembelajaran berlangsung hanya $67 \%$, siswa menjawab pertanyaan saat diskusi antar kelompok hanya $63 \%$. Sedangkan hal yang bersifat negatif dari aktivitas belajar siswa adalah masih ada siswa tidak mengerjakan latihan soal yang diberikan guru, berbicara masalah lain saat kerja kelompok, diam saja saat proses belajar berlangsung (karena tidak mengerti), tidak konsentrasi saat belajar sehingga masih banyak siswa yang dibantu secara individual oleh guru.

\section{Siklus Kedua}

Secara umum aktivitas siswa belajar biologi pada siklus kedua mengalami peningkatan dibanding dengan siklus pertama. Pada siklus kedua ini tampak siswa mengalami peningkatan pemahaman materi yang dipelajari. 
Tabel 3. Hasil observasi aktivitas belajar siswa dalam proses pembelajaran pada siklus kedua

\begin{tabular}{|c|l|c|c|c|c|}
\hline \multirow{2}{*}{ No } & \multicolumn{1}{|c|}{ Aktivitas siswa } & \multicolumn{2}{|c|}{ Pertemuan } & Rata- & \multirow{2}{*}{$\%$} \\
\cline { 3 - 5 } & & 1 & 2 & rata & \\
\hline 1 & Siswa bertanya saat proses pembelajaran berlangsung & 15 & 8 & 11.5 & 44 \\
\hline 2 & Siswa menjawab pertanyaan saat diskusi antar kelompok & 18 & 24 & 21.0 & 81 \\
\hline 3 & Siswa mengerjakan latihan soal yang diberikan guru & 24 & 26 & 25.0 & 96 \\
\hline 4 & $\begin{array}{l}\text { Siswa berbicara tentang masalah lain saat pembelajaran } \\
\text { berlangsung }\end{array}$ & 1 & 0 & 0.5 & 2 \\
\hline 5 & Siswa diam saja saat proses pembelajaran berlangsung & 8 & 3 & 5.5 & 21 \\
\hline 6 & Siswa tidak konsentrasi saat belajar & 2 & 0 & 1.0 & 4 \\
\hline 7 & Siswa diberi pujian atau penguatan oleh guru saat belajar & 15 & 22 & 18.5 & 71 \\
\hline 8 & $\begin{array}{l}\text { Siswa dibantu secara individual dalam menyelesaikan } \\
\text { soal-soal dalam kelompok kecil }\end{array}$ & 8 & 3 & 5.5 & 21 \\
\hline & Rata-rata & & & 11.1 & \\
\hline
\end{tabular}

Sumber: Jurnal pembelajaran guru)

Tabel 3 diatas, menunjukkan bahwa aktivitas siswa belajar biologi mengalami peningkatan. Siswa yang bertanya saat proses pembelajaran berlangsung $44 \%$, hal ini menurun karena banyak siswa yang sudah mengerti langkah-langkah penyelesaian soal sehingga mereka sangat serius dalam mengerjakan latihan, siswa menjawab pertanyaan dari soal-soal saat diskusi antar kelompok $81 \%$, Siswa mengerjakan latihan soal yang diberikan guru 96\%, siswa berbicara tentang masalah lain saat pembelajaran berlangsung $2 \%$, siswa diam saja saat proses belajar sedang berlangsung $21 \%$ hal ini mengalami penurunan karena sudah banyak siswa yang mengerti dalam memecahkan soal, siswa tidak konsentrasi saat proses belajar berlangsung menjadi 4\%, siswa diberi pujian atau penguatan oleh guru $71 \%$, siswa dibantu oleh guru secara individual dalam menyelesaikan soal-soal dalam kelompok kecil $21 \%$.

\section{Hasil Belajar Siklus II}

Data kalkulasi nilai harian sebagai hasil belajar siswa pada siklus II adalah sebagai berikut:

Tabel 4. Nilai rata-rata hasil belajar siswa dalam menyelesaikan soal-soal substansi Genetika pada akhir siklus II (KKM = 73)

\begin{tabular}{|c|c|c|c|c|}
\hline No & Nilai & Jumlah Siswa & Tuntas & Tidak Tuntas \\
\hline 1 & $<49$ & 0 & 0 & 0 \\
\hline 2 & $50-59$ & 0 & 0 & 0 \\
\hline 3 & $60-69$ & 1 & 0 & 1 \\
\hline 4 & $70-79$ & 4 & 3 & 1 \\
\hline 5 & $80-89$ & 14 & 14 & 0 \\
\hline 6 & $90-100$ & 9 & 9 & 0 \\
\hline & Jumlah & 28 & 26 & 2 \\
\hline & Persentase & & $93 ., 55$ & 6,45 \\
\hline
\end{tabular}

Sumber: Tabulasi data, 2019 
Dari total rata-rata perolehan nilai siswa sudah mengalami peningkatan, persentase ketuntasan sudah mecapai 93,55\%. Hal ini membuat siswa semakin antusias untuk terus belajar dan berdiskusi membahas materi pelajaran menggunakan model pembelajaran Example Non Example.

\section{Refleksi}

Beberapa hal positif yang dapat dikemukakan dari siklus kedua adalah siswa sudah mengerti langkah-langkah pengerjaan soal-soal sehingga jumlah siswa yang bertanya mengenai cara pengerjaan soal latihan menurun dan siswa sangat serius dalam mengerjakan latihan, siswa menjawab pertanyaan pada saat diskusi antar kelompok meningkat $81 \%$ dari $63 \%$ pada siklus pertama. Tidak ada lagi siswa yang berbicara masalah lain dan tidak berkosentrasi saat belajar pada akhir siklus II. Walaupun masih ada siswa yang tetap harus dibimbing secara individual dalam mengerjakan latihan soal-soal latihan, atau dapat dilihat pada grafik dibawah ini mengenai peningkatan aktivitas belajar siswa dalam pembelajaran biologi khususnya pada materi Substansi Genetika dan Hereditas Mendel pada siklus I dan siklus II.

\section{PEMBAHASAN}

Data hasil belajar yang diperoleh dikatakan meningkat apabila hasil belajar yang diperoleh dari siklus kedua lebih tinggi dari hasil belajar siklus pertama Dimana pada penelitian ini peneliti menggunakan hasil tes ulangan harian sebagai titik awal untuk melihat peningkatan pada hasil belajar siswa. Dari tabel diatas, setelah dianalisis, diatas terlihat bahwa rata-rata nilai siswa mengalami peningkatan. Pada siklus I rata-rata dari 62 pada pertemuan I meningkat menjadi 74 pada pertemuan 2, sedangkan pada siklus II adalah 83 pada pertemuan 1 dan meningkat menjadi 93 pada pertemuan 2 .

Tabel 5. Hasil penilaian dan kalkulasi hasil tes siswa pada siklus I dan siklus II

\begin{tabular}{|l|c|c|c|c|}
\hline \multirow{2}{*}{} & \multicolumn{2}{|c|}{ Siklus I } & \multicolumn{2}{c|}{ Siklus II } \\
\cline { 2 - 5 } & Pertemuan 1 & Pertemuan 2 & Pertemuan 1 & Pertemuan 2 \\
\hline Jumlah & 1918 & 2281 & 2577 & 2874 \\
\hline $\begin{array}{l}\text { Ketuntasan } \\
\text { Klasikal (\%) }\end{array}$ & 16 & 45 & 77 & 97 \\
\hline Rata-rata & 62 & 74 & 83 & 93 \\
\hline
\end{tabular}

Sumber: Tabulasi data, 2019

Dari tabel 5 diatas, setelah dianalisis, terlihat bahwa ketuntasan klasikal persiklus pada mata pelajaran biologi mengalami peningkatan sesuai KKM yang ditentukan yaitu 75. Pada siklus I ketuntasan klasikal pertemuan $\mathrm{I}=16 \%$ dan pertemuan II $=45 \%$, sedangkan pada siklus II meningkat pada pertemuan $\mathrm{I}=77 \%$ dan pertemuan II meningkat menjadi 97\%. Rata-rata nilai harian peserta didik dapat dilihat pada grafik 1 berikut : 


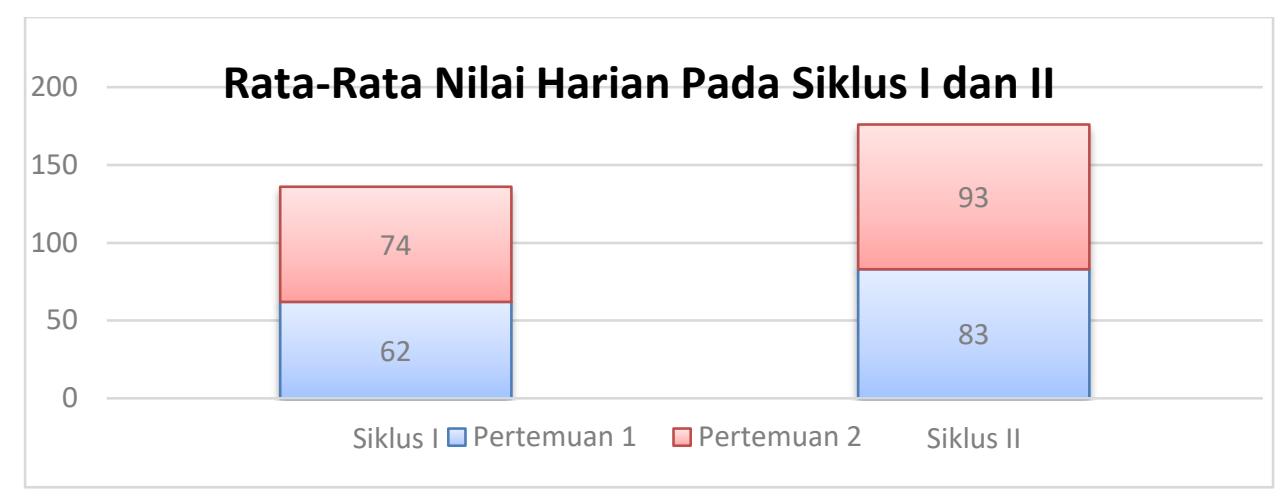

Grafik 1. Rata-rata Nilai Harian mata pelajaran Biologi pada Sikus I dan Siklus II, peremuam 1 dan pertemuan 2

Dengan memperhatikan hasil observasi terhadap aktivitas siswa dalam pembelajaran biologi menggunakan model pembelajaran Example Non Example menunjukkan adanya peningkatan dalam kemampuan siswa memahami materi khususnya materi Substansi Genetika. Dari hasil belajarpun siswa menunjukkan peningkatan dilihat dari rata-rata hasil belajar yang didapatkan yaitu rata-rata dari 62 meningkat menjadi 74 pada siklus I, dan rata-rata 83 meningkat menjadi 93 pada siklus II. Hal ini menunjukkan model pembelajaran Example Non Example sangat efektif dipakai dalam materi biologi yang berhubungan dengan perhitungan matematika dan studi kasus khususnya materi substansi genetika.

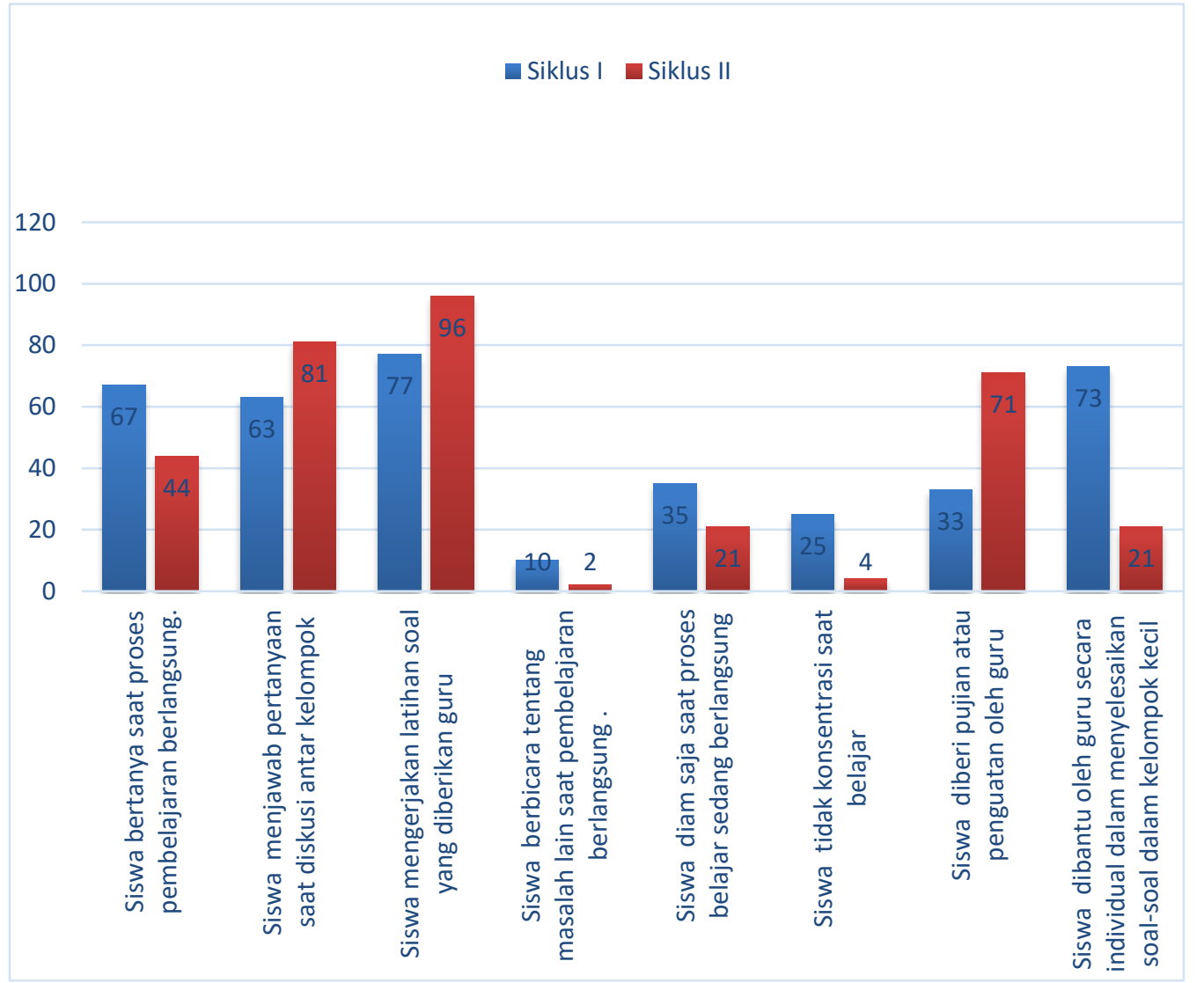

Grafik 1. Hasil Observasi Aktivitas Belajar Siswa Dalam Proses Pembelajaran pada Siklus I dan Siklus II 


\section{KESIMPULAN DAN SARAN}

Peneliti menyimpulkan bahwa dengan model pembelajaran Example Non Example telah dapat meningkatkan aktivitas siswa secara signifikan yaitu rata-rata dari 28 siswa yang mau bertanya meningkat dari 2 siswa pada siklus I menjadi 7 siswa pada siklus II menjadi 15 siswa. Hal seperti ini dapat dikatakan bahwa kemauan siswa untuk bertanya mengalami kemajuan yang sangat pesat. siswa yang mau menjawab pertanyaan meningkat dari 3 siswa pada siklus I menjadi 5 siswa pada siklus II dan menjadi 17. Model pembelajaran Example Non Example telah meningkatkan hasil belajar siswa yaitu pada siklus I rata-rata ketuntasan 53,29, siklus II adalah 77,42\% dan siklus III meningkat menjadi 80,16\%.

Peneliti menyarankan untuk dapat model pembelajaran Example Non Example untuk dapat meningkatkan aktivitas siswa dan model pembelajaran Example Non Example untuk meningkatkan hasil belajar siswa, sebagai alternatif dalam pembelajaran biologi.

\section{DAFTAR PUSTAKA}

Alkrismanto.2003. Beberapa Teknik, Model dan Strategi dalam Pembelajaran Matematika . Disampaikan pada acara pelatihan Instruktur / Pengembangan SMU tanggal 28 Juli s/d 10 Agustus 2003.(Tidak dipublikasikan). Pdf. Diakses tanggal 2 April 2012.

Muslimin. (2001). Pembelajaran Kooperatif. Surabaya: University Press.

Mulyasa.E ( 2005 ). Implementasi Kurikulum 2004 Panduan Pembelajaran KBK, Remaja Rosdakarya:Bandung.

Nana Sudjana, Dasar-dasar Proses Belajar Mengajar, (Bandung : Sinar Baru, 1989), hlm.2

Prawoto, dkk, Pemahaman Guru-guru Biologi SMA Kota Madya Yogyakarta Terhadap Strategi Belajar Mengajar (Makalah), ( Yogyakarta : IKIP Yogyakarta, 1992), hlm.9

Sudjana.N.( 2004 ). Penilaian Hasil Proses Belajar Mengajar. Remaja Rosdakarya:Bandung.

Sadirman, AM. (2006). Interaksi dan Motivasi Belajar Mengajar. Jakarta: CV Rajawali.

Wuryadi, Konsep Pendidikan Biologi dan Implementasinya dalam Penelitian, (Yogyakarta : FMIPA UNY, 1999), hlm.1

............2012. Example Non Example (online). (http://pakifank.blogspot.com/ 2012/04/example-non-example.html). Diakses tanggal 12 Oktober 2012. ..2011. Hakikat Pembelajaran Biologi(on line). (http://pawitriyadi87.blogspot.com/2011/12/hakikat-pembelajaranbiologi.html). Diakses tanggal 12 Oktober 2012. 